\title{
Infantile parotid haemangioma: a report of three cases
}

Naczyniak ślinianki przyusznej u dzieci: opis trzech przypadków

\author{
'Department of Otorhinolaryngology, Hospital Tuanku Ja'afar, Jalan Rasah, 70300 Seremban, Negeri Sembilan, Malaysia \\ 2 Department of Otorhinolaryngology, Faculty of Medicine, University of Malaya, Jalan Universiti, 50603 Kuala Lumpur, Malaysia \\ ${ }^{3}$ Department of Otorhinolaryngology, Hospital Umum Sarawak, Jalan Hospital, 93586 Kuching, Sarawak. Malaysia \\ Correspondence: Jeyasakthy Saniasiaya, Department of Otorhinolaryngology, Faculty of Medicine, University of Malaya, Jalan Universiti, 50603 Kuala Lumpur, Malaysia, e-mail: shakthy_18@yahoo.com
}

Abstract Aim of this case: To highlight the presentation of rapidly enlarging parotid haemangioma in three children who were all successfully managed with oral propranolol. Case report: Parotid haemangioma in infancy, albeit rare, has been vastly reported due to it being the most common tumour of the salivary gland in infants. Despite that, the presence of a rapidly enlarging tumour in "the little ones" may be daunting, leading to countless unwarranted procedures by attending physicians. Herein, we present three cases of infantile rapidly tumefying parotid lesions which were diagnosed clinically with the support of imaging, and successfully managed by promptly initiating oral propranolol. Conclusion: Although several recent reports have been reviewed, the challenges in diagnosis and management of the condition need to be individualised.

Keywords: salivary gland neoplasms, haemangioma, paediatrics

Streszczenie Cel pracy: Przedstawienie trzech przypadków szybko rozprzestrzeniającego się naczyniaka ślinianki przyusznej u dzieci z powodzeniem leczonych propranololem doustnie. Opisy przypadków: Chociaż naczyniak ślinianki przyusznej występuje w okresie niemowlęcym rzadko, jest dość dokładnie opisany jako najczęstszy nowotwór gruczołu ślinowego u niemowląt. Niezależnie od tego obecność szybko powiększającego się guza u „najmłodszych pacjentów” może być wyzwaniem diagnostycznym dla wielu lekarzy, skutkując wykonywaniem licznych nieuzasadnionych procedur. W niniejszej pracy przedstawiono trzy przypadki zmian umiejscowionych w śliniance przyusznej u niemowląt, w których ustalono rozpoznanie naczyniaka na podstawie obrazu klinicznego przy wsparciu badań obrazowych. Pacjentów skutecznie leczono sposobem wczesnego zastosowania propranololu doustnie. Wniosek: Na podstawie zaprezentowanych przypadków i przeglądu najnowszych doniesień literaturowych należy uznać, że wyzwania związane z diagnostyką i leczeniem naczyniaka ślinianki przyusznej wymagają zindywidualizowanego podejścia do chorych.

Słowa kluczowe: nowotwory gruczołów ślinowych, naczyniak, pediatria 


\section{INTRODUCTION}

I nfantile haemangiomas $(\mathrm{IH})$ are the most common vascular tumours found during the period of infancy period and characterised by abnormal proliferation of endothelial cells and aberrant blood vessel architecture ${ }^{(1,2)}$. Salivary glands are the most common organs affected by the lesions. It is noteworthy that nearly $90 \%$ of salivary gland haemangiomas arise within the parotid gland ${ }^{(3)}$. Parotid haemangioma has shown a predilection towards female patients, with a ratio of 3:1 $1^{(4-6)}$. Salivary gland haemangiomas can be divided into congenital, i.e. present at birth, and infantile, i.e. the more common variant which usually proliferates from original pink macules during the first two months of life $\mathrm{e}^{(1)}$. Parotid haemangioma demonstrates rapid growth in first months of life but usually regresses after 18 months $^{(5)}$. We report three cases of infantile parotid haemangioma which were successfully treated with oral propranolol. We would like to highlight that attending physician should be cognizant of this entity amongst infants as to avoid unnecessary aggressive procedures.

\section{CASE PRESENTATION}

\section{Case 1}

A two-month-old girl presented with one-month history of right preauricular swelling which gradually increased in size. According to her parents, there had been no inciting trauma or fall, and no prior upper respiratory infections. The antenatal history was unremarkable, and the baby was vaccinated as per protocol. In addition, the child tolerated breast-feeding well.
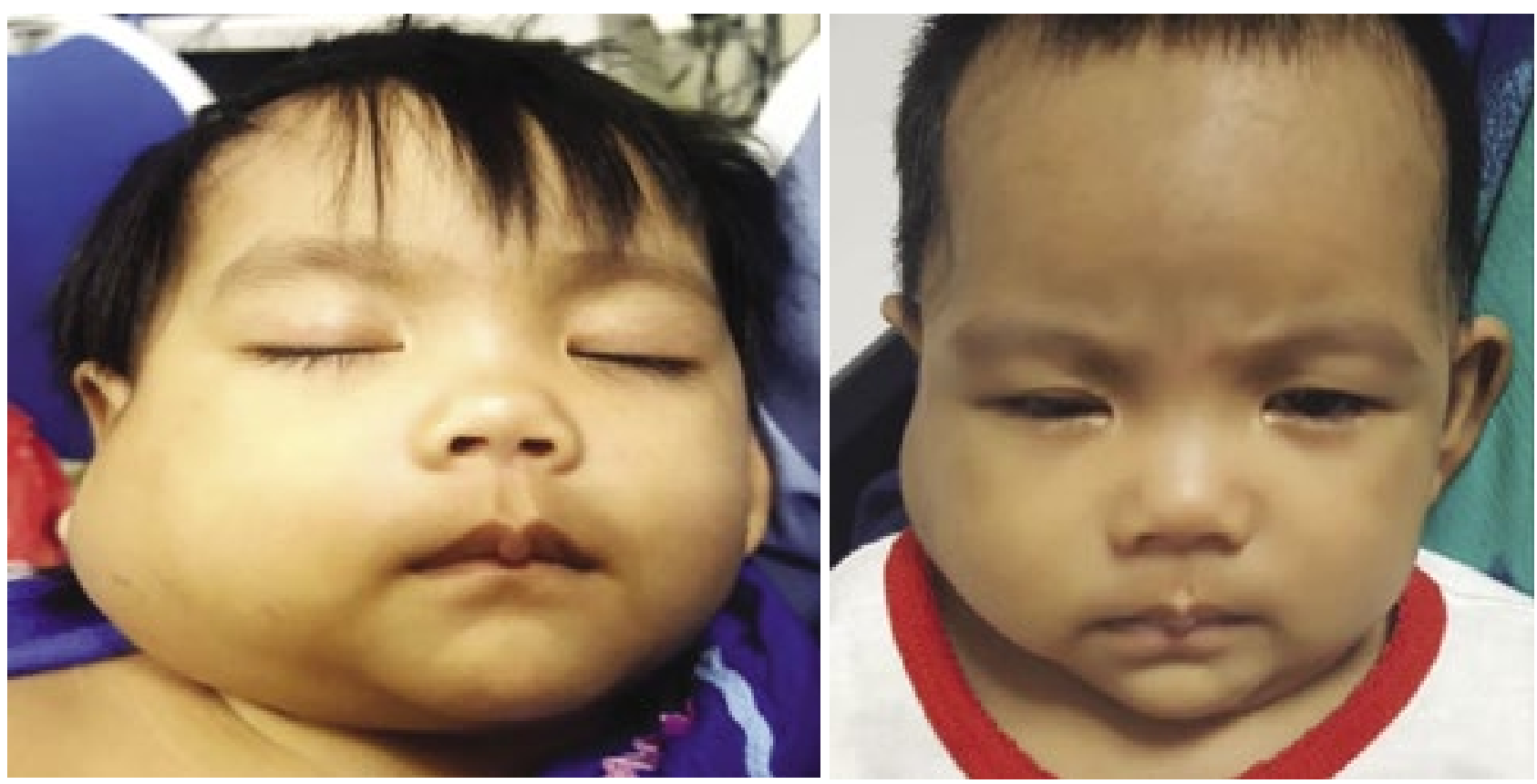

On physical examination, the child appeared active. The right preauricular swelling was noted to be cystic and non-tender. The overlying skin appeared bluish (Fig. 1). A trial of oral antibiotic was given for a week, but the swelling appeared to tumefy. Intraoral examination showed no medialisation. An ultrasound scan of the neck revealed a homogenous enlarged parotid gland, measuring $3.0 \times 3.8 \times 3.6 \mathrm{~cm}$, with no significant increase in Doppler signal. In the next step, computed tomography (CT) of the neck was done, demonstrating a homogenous, avidly enhancing mass in the right parotid, measuring $4.4 \times 4.3 \times 5.0 \mathrm{~cm}$, and involving superficial and deep lobes suggestive of an IF (Fig. 2). The parents were counselled, and the child was started on oral propranolol after cardiac and blood sugar examinations were performed. After one month of oral propranolol treatment, the swelling was found to have reduced tremendously in size. The child is on regular follow-up and, oral propranolol is adjusted accordingly.

\section{Case 2}

A two-month-old baby girl presented with rapidly progressing left preauricular swelling for the preceding two weeks. According to her parents, the swelling was initially very small but progressively increasing, causing torticollis. There had been no inciting trauma or fever. No other leno shortness of breath or stridor, and the child tolerated breast-feeding well.

Upon examination, the child appeared comfortable under room air. Huge, cystic left preauricular swelling was seen, causing torticollis. Externally bluish skin discoloration was noted. An ultrasound scan of the neck was scheduled to sions or skin discoloration were noted elsewhere. There was

Fig. 1. Right preauricular swelling: pre-treatment and post-treatment 


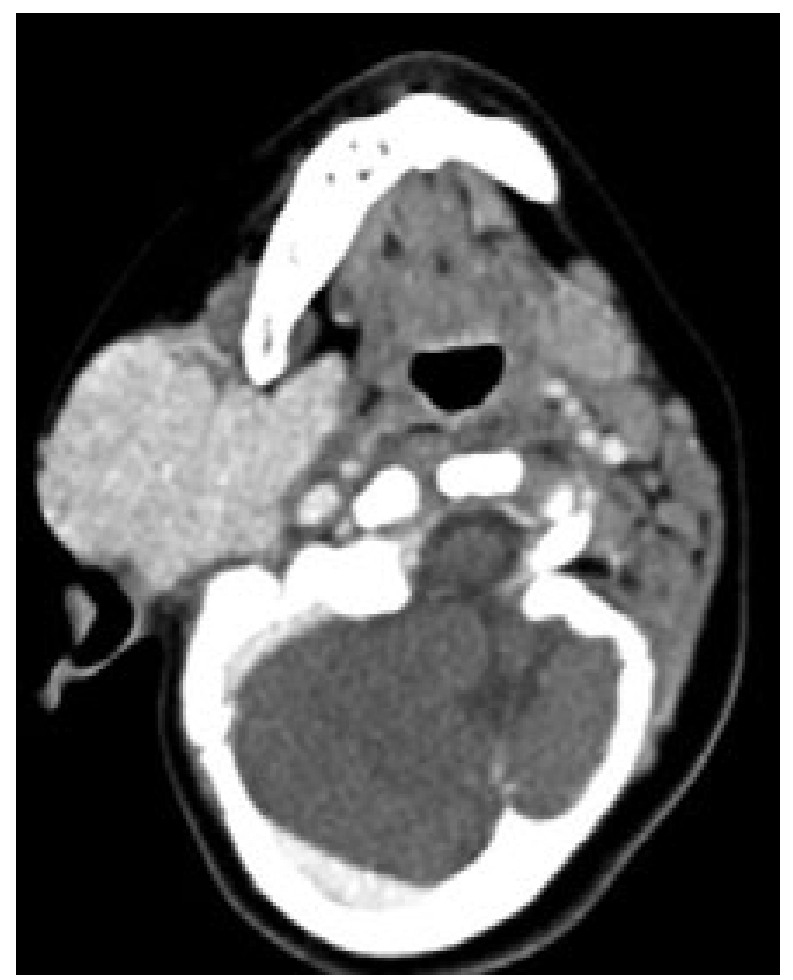

Fig. 2. Right homogenous, avidly enhancing mass occupying the superficial and deep lobes of the parotid gland

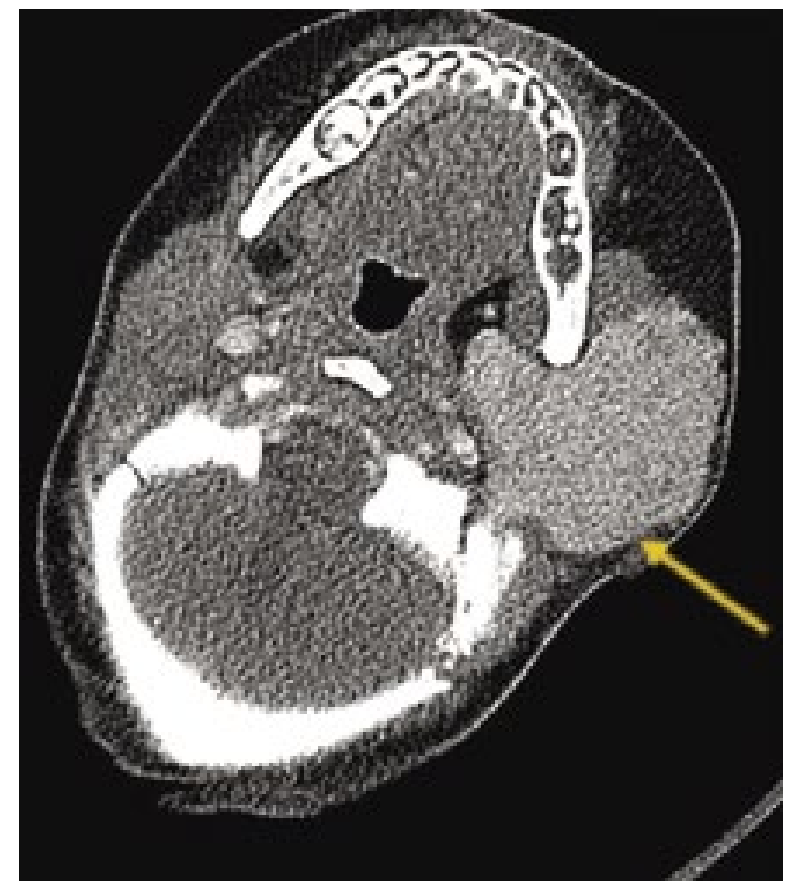

Fig. 3. Homogenous enhancing mass over the left parotid gland

be performed during the next two weeks, however, the size of the preauricular mass increased abruptly within a week, so the child was admitted for observation. All blood parameters were within the normal range. CT of the neck revealed homogenous enhancing enlargement of the left parotid gland, with retention of its shape and preservation of the lobular pattern (Fig. 3). The findings were in keeping with left parotid haemangioma. After discussion with both parents, oral propranolol was commenced. Cardiac and blood sugar examination were undertaken prior to the initiation of oral propranolol treatment. During subsequent follow-up, the parotid mass showed a remarkable reduction in size, so the dose of oral propranolol was adjusted accordingly (Fig. 4).

\section{Case 3}

A three-month-old baby girl presented with a two-month history of right preauricular swelling that gradually increased in size. The child had no obstructive symptoms and tolerated breast-feeding well. Additionally, no prior inciting trauma or fall had been noted.

Upon examination, the child was comfortable under room air, with no noisy breathing. There was a huge, cystic right preauricular mass, measuring $6 \times 8 \mathrm{~cm}$, with erythematous overlying skin. Ultrasound of the neck revealed homogenous swelling with increased Doppler signal. After evaluation by the paediatrics team, the parents were counselled, and treatment with oral propranolol was commenced. One month after starting the treatment the swelling was noted to have reduced significantly, and the dose of oral propranolol was adjusted accordingly.

\section{DISCUSSION}

IH has been reported as the most common soft tissue tumour amongst infants. Besides female predilection, the entity was demonstrated in premature babies and is more common in the white population ${ }^{(7)}$. Apart from that, major risk factors include advanced maternal age, multiple pregnancies as well as complicated pregnancies including preeclampsia and placenta previa ${ }^{(8)}$.

In a study of 56 children with IH of the parotid gland, 70\% were females ${ }^{(4)}$. Our patients were girls as well. A small parotid swelling may be present since birth. However, it usually develops within the first six months of age, with rapidly enlarging parotid swelling (proliferative phase) which spontaneously regresses by one to seven years of age $\mathrm{e}^{(6)}$. Similarly, in our case, both patients presented with rapidly enlarging parotid swelling at two months of age. Clinically, parotid gland haemangiomas present as asymptomatic soft tissue swellings that cause the overlying skin to obtain a bluish hue $\mathrm{e}^{(9)}$. Although the condition is benign and self-limiting, severe and life-threatening complications can arise in some cases. IH over the parotid region often causes deformity of the adjacent structures, narrowing of the external auditory canal or even facial nerve palsy. Also, high blood volumes circulating within larger lesions may contribute to congestive heart failure ${ }^{(3)}$.

Meticulous history taking along with thorough physical examination always play a huge role in the diagnostic workup of this condition. Nevertheless, there are numerous 


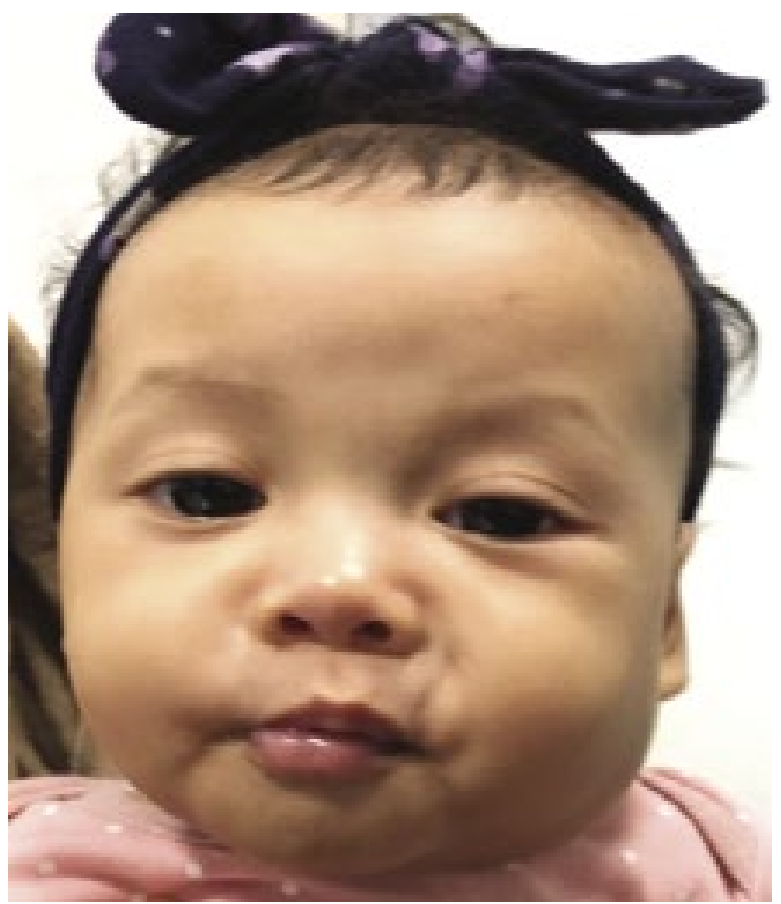

Fig. 4. Post-treatment: a significant reduction

differential diagnostic entities that can be mistakenly diagnosed as IH. Acute parotitis is the main differential diagnosis of IH of the parotid. However, a child with acute parotitis will present with fever and swelling, and also can have erythema in the preauricular region. In our first case, we initially treated the child for acute parotitis, but after a week of antibiotic treatment the swelling failed to subside. On sonography, the parotid gland is typically enlarged and heterogeneous, with enlarged intraparotid lymph nodes. Hypoechoic foci may indicate areas of suppuration ${ }^{(10)}$.

Vascular and lymphatic malformations of the parotid gland can also present in infancy. However, the slow flow nature of these lesions is readily demonstrated by sonography. Venous malformations are seen as multiple hypoechoic channels that compress readily and refill with blood on removal of compression. Phleboliths may or may not be seen. Lymphatic malformations (LM) involving the parotid gland can be either macrocystic or microcystic. A macrocystic LM is typically seen as a well-defined, multilocular anechoic or hypoechoic lesion without internal flow. Fluid/fluid levels may also be identified if there is intralesional haemorrhage. On sonography, a microcystic LM has the appearance of an echogenic mass, with small channels, but no discernible cysts $^{(10)}$. A study by Gontarz et al. in 2018 shows that pleomorphic adenoma is a common benign tumour in paediatric patients, while mucoepidermoid carcinoma is a common malignant tumour affecting the parotid gland ${ }^{(11)}$.

Ultrasound is usually the primary imaging modality done to establish the diagnosis of IH of the parotid gland. It demonstrates a well-circumscribed homogenously hypoechoic enlarging mass, replacing most of the parotid gland. The le- internal septations. However, the overall shape of the parotid gland is well maintained, and no significant extension is seen beyond the gland. The lesion shows numerous large intratumoural blood vessels, which is confirmed by the application of colour Doppler ${ }^{(5)}$.

CT may further demonstrate well-circumscribed tumours with distinct lobular architecture. In addition to that, the involvement of deep structures may be shown. However, there is no evidence of perilesional oedema, stranding or enhancement $^{(9)}$.

Magnetic resonance imaging, on the other hand, appears hypointense on T1WI and hyperintense on T2WI, with prominent flow voids and uniform contrast enhancement. Involuting haemangiomas may show areas of hyperintensities on T1WI due to fatty replacement ${ }^{(5)}$.

Biopsy is considered to be an invasive procedure in children. In IH, biopsy is often avoided on account of the risk of injury to the facial nerve which has a more superficial course in infancy ${ }^{(12)}$. However, fine needle aspiration cytology can be performed in order to distinguish between benign and malignant neoplasms. The specificity of fine-needle aspiration cytology is estimated at $96 \%{ }^{(13)}$. Khurana and Mortelliti showed that the cytologic diagnosis of spindle cell proliferation consistent with IH was rendered in all cases included in their study ${ }^{(14)}$.

Although haemangiomas often regress without treatment, rapid growth of parotid haemangioma can cause ulceration, potential life-threatening airway obstruction, and a possible risk of delayed language acquisition resulting from aural involvement and abnormal auditory conduction.

This complication usually requires a non-surgical and/or surgical intervention. Previously, corticosteroids and interferon alfa were used to treat haemangiomas. There have been a few studies demonstrating the efficacy of propranolol when compared to corticosteroids ${ }^{(15,16)}$. In our cases, the initiation of oral propranolol was based on the patients' body weight. We use the dose of $2 \mathrm{mg}$ per $\mathrm{kg}$ per day for 6 months in the treatment of IF. Patients are hospitalised for cardiac and blood sugar monitoring for at least three days. The efficacy of propranolol was described back in 2008, when a child with cardiomyopathy receiving propranolol was noted to have had a significant reduction in the size of nasal haemangioma. In this study, the researchers proposed three possible mechanisms of action including vasoconstriction to explain the rapid (occurring within days) softening of the lesions, decreased expression of the vascular growth factors VEGF and bFGF through the downregulation of their genes by the RAF mitogen-activated protein kinase pathway, and finally activation of apoptosis of capillary endothelial cells ${ }^{(11)}$.

Surgical intervention is usually reserved for patients with poor response to medical treatment. However, the risk of facial nerve injury and increased blood loss must be considered due to proximity to the facial nerve. Furthermore, incomplete resection resulted in regrowth of haemangioma ${ }^{(10)}$. Reinisch et al. documented the results obtained in 
17 patients with a broad age distribution who had undergone surgical resection for parotid haemangiomas. The indications for surgery included marked facial deformity with or without functional compromise, lack of response to other treatment modalities, difficult parental acceptance, or failure to regress sufficiently with time. Two patients had transient facial nerve palsy which resolved, and their postoperative results were reported to be excellent ${ }^{(17)}$. In both our cases, oral propranolol showed a remarkable reduction in swelling size, so surgical intervention is not considered at the moment.

\section{CONCLUSION}

In conclusion, the diagnostic work-up in parotid haemangioma needs to combine good history taking with physical examinations. Imaging evaluations, such as ultrasound and CT scans, must be done to confirm the diagnosis. Treatment with oral propranolol as the first line helps to achieve a significant reduction in the size of parotid haemangioma.

\section{Conflict of interest}

The authors do not report any financial or personal affiliations to persons or organisations that could adversely affect the content of or claim to have rights to this publication.

\section{References}

1. Tweedie DJ, Hartley BEJ: Haemangiomas and vascular malformations. In: Watkinson JC, Clarke RW (eds.): Scott-Brown's Otorhinolaryngology Head and Neck Surgery. Vol. 2, CRC Press, Boca Raton, FL 2018: 477-490.

2. Darrow DH, Greene AK, Mancini AJ et al.; Section on Dermatology, Section on Otolaryngology-Head and Neck Surgery, and Section on Plastic Surgery: Diagnosis and management of infantile hemangioma. Pediatrics 2015; 136: e1060-e1104.
3. Ma X, Chang M, Ouyang T et al.: Combination of propranolol and sclerotherapy for treatment of infantile parotid hemangiomas. Int J Clin Exp Med 2015; 8: 10865-10874.

4. Mantadakis E, Tsouvala E, Deftereos S et al.: Involution of a large parotid hemangioma with oral propranolol: an illustrative report and review of the literature. Case Rep Pediatr 2012; 2012: 353812.

5. John DR, Shingade R, Patel J: A case of parotid hemangioma of infancy: role of ultrasound and Doppler in the diagnosis. Indian Journal of Neonatal Medicine and Research 2016; 4: 10-12.

6. Chaubal $\mathrm{R}$, Tavri O, Sawant A et al.: Infantile hemangioendothelioma of the parotid gland. J Clin Imaging Sci 2017; 7: 5.

7. Metry DW, Hebert AA: Benign cutaneous vascular tumors of infancy: when to worry, what to do. Arch Dermatol 2000; 136: 905-914.

8. Paller AS, Mancini AJ: Hurwitz Clinical Pediatric Dermatology. $4^{\text {th }}$ ed., Elsevier, Edinburg 2011: 268-275.

9. Harris J, Phillips JD: Evaluating the clinical outcomes of parotid hemangiomas in the pediatric patient population. Ear Nose Throat J 2021; 100: NP242-NP245.

10. Weber FC, Greene AK, Adams DM et al.: Role of imaging in the diagnosis of parotid infantile hemangiomas. Int J Pediatr Otorhinolaryngol 2017; 102: 61-66.

11. Gontarz M, Wyszyńska-Pawelec G, Zapała J: Primary epithelial salivary gland tumours in children and adolescents. Int J Oral Maxillofac Surg 2018; 47: 11-15.

12. Huchzermeyer P, Birchall MA, Kendall B et al.: Parotid haemangiomas in childhood: a case for MRI. J Laryngol Otol 1994; 108: 892-895.

13. Daneshbod Y, Daneshbod K, Khademi B: Diagnostic difficulties in the interpretation of fine needle aspirate samples in salivary lesions: diagnostic pitfalls revisited. Acta Cytol 2009, 53: 53-70.

14. Khurana KK, Mortelliti AJ: The role of fine-needle aspiration biopsy in the diagnosis and management of juvenile hemangioma of the parotid gland and cheek. Arch Pathol Lab Med 2001; 125: $1340-1343$.

15. Léauté-Labrèze $\mathrm{C}$, Dumas de la Roque $\mathrm{E}$, Hubiche $\mathrm{T}$ et al.: Propranolol for severe hemangiomas of infancy. N Engl J Med 2008; 358: 2649-2651.

16. Sadykov RR, Podmelle F, Sadykov RA et al.: Use of propranolol for the treatment infantile hemangiomas in the maxillofacial region. Int J Oral Maxillofac Surg 2013; 42: 863-867.

17. Drolet BA, Frommelt PC, Chamlin SL et al.: Initiation and use of propranolol for infantile hemangioma: report of a consensus conference. Pediatrics 2013; 131: 128-140. 